\title{
Effects of closing date on seeding and hardseededness of balansa, gland, Persian and arrowleaf clovers on East Coast dryland
}

\author{
M.J. MACFARLANE ${ }^{1}$, E.W. CROFOOT ${ }^{2}$ and P.D. MUIR ${ }^{1}$ \\ ${ }^{1}$ On-Farm Research Limited, P.O. Box 1142, Hastings, New Zealand \\ ${ }^{2}$ Castlepoint Station, RD 9, Masterton, New Zealand \\ paul@on-farm.co.nz
}

\begin{abstract}
Four annual clovers (Arrowleaf (Trifolium versiculosum), balansa (T. michelianum), Persian ( $T$. resupinatum) and gland (T. glanduliferum)) were sown on five East Coast dryland farms and one moist Taranaki site. Hardseededness was measured at all sites and seed production and hardseededness was measured at three sites following different closing dates. There were no differences in seed size for any species between sites or closing dates. High levels of seed (500-700 kg/ha) were set by balansa and arrowleaf clovers after an early closing date (early September). Flowering and seed production decreased with later closings. Gland clover was the earliest to flower and with Persian clover was very susceptible to early grazing. Gland clover produced virtually no seed as flowers had already been grazed prior to the first closing. Arrowleaf clover produced very high levels (>92\%) of hard seed and Persian very low levels $(<1 \%)$. Lack of hardseededness led to Persian clover seed being lost to false strikes, with most seed germinating in the seed head following January and February rains. Balansa, when carefully managed, appears to be the only annual clover which regenerates in its second season in East Coast dryland conditions.
\end{abstract}

Keywords: arrowleaf clover, Persian clover, balansa clover, gland clover, hard seed, seed production.

\section{Introduction}

An increasing frequency and intensity of droughts in North Island east coast hill country has led to a search for more robust farming systems. Droughts provide challenges for the persistence of traditional white clover so it seems sensible to examine annual legumes that have shown promise in Australia.

Arrowleaf (Trifolium versiculosum), balansa ( $T$. michelianum), Persian (T. resupinatum) and gland (T. glanduliferum) clovers are relatively new to New Zealand farming and may have promise in summer dry areas. All grow vigorously during spring but are aerial seeders. With the exception of some cultivars of Persian clover, all produce large amounts of hard seed. Whilst arrowleaf, Persian and balansa have been historically tested within New Zealand research institutes (Williams et al. 1980; Sheath et al. 1984; Hyslop et al. 2003), little farm use has occurred.

Arrowleaf clover is native to the Mediterranean, has upright stems up to $100 \mathrm{~cm}$ tall, but has poor tolerance to water logging and does not tolerate competition at establishment (Anon 2003). It has been shown to persist in areas of Australia which receive 500-600 $\mathrm{mm}$ of annual rainfall (Evans 2006) and recent research indicated that it may be suitable for dryland New Zealand (Evans \& Mills 2008).

Balansa clover is native to the Mediterranean region (Craig 1998) and is used in areas of Australia receiving 350-600 mm annual rainfall (Craig \& Ballard 2000). When grown with cocksfoot (Dactylis glomerata) in lowland Canterbury, balansa clover contributed an average of $28 \%$ of the total annual dry matter (DM) over 6 years (Monks et al. 2008). Dry matter production increased significantly in the second year after the initial heavy seed set. In addition, more than 10 times the amount of seed initially sown was present as hard seed in the soil at the end of autumn in the second year. This suggests that balansa clover has the capacity to produce a large seed bank that can be managed for regeneration in subsequent years.

Gland clover originates from Israel (Nutt \& Loi 2002) and has an upright open habit and which can lodge as it matures. Stems are typically $400-500 \mathrm{~mm}$ long. It produces the smallest seed of these annual clovers (Hackney et al. 2007). Studies conducted in New South Wales, Australia found that gland clover out-yielded subterranean clover in the first year but declined rapidly as it struggled to compete with subterranean clover seedlings in the autumn (Dear et al. 2002).

Persian clover is native to wider Persia (Turkey, Afghanistan, Iraq, Iran) and Greece (Anon. 2003) and is used in temperate dryland pastures of southern Australia. Persian clover is very tolerant of waterlogged soils during winter (Gibberd \& Cocks 1997), and has some tolerance to saline conditions (Evans \& Snowball 1993). There are two subspecies of Persian clover: $T$. resupinatum var. resupinatum and $T$. resupinatum var. majus. T. resupinatum var. resupinatum has a more prostrate growth habit, produces hard seed and has thinner stems and smaller leaflets and flowers earlier than most cultivars of majus. T. resupinatum var. majus types produce little hard seed (Anon. 2003). 
A demonstration in southern Marlborough at near the Clarence Bridge River mouth, using very high seeding rates, reported that Persian, balansa and arrowleaf clovers produced 8.3, 7.2 and 6.9 tonnes $\mathrm{DM} /$ ha, respectively, between sowing on 26 March and harvest on 31 August (Anon. 2012). Arrowleaf clover was measured growing at $153 \mathrm{~kg} \mathrm{DM} / \mathrm{ha} /$ day at Lincoln (Evans \& Mills 2008). These reports led to these annual clovers being incorporated into the Future Forage Systems project. This project has the objective of evaluating the performance and management of "new" forages and benchmarking them within existing farm situations.

\section{Methods}

Five plantain and annual clover swards were established on farms in summer dry areas of Hawke's Bay and the Wairarapa (Table 1). At three additional sites, annual clovers were sown as monocultures either on a paddock or plot scale. The sites were located in the Hastings area, coastal Wairarapa and Taranaki. Seed production and seed characteristics (size, hardseededness) were measured following different closing dates at three farm sites. At other sites only seed characteristics were measured.

At Te Mahanga Station (TEM-P) 38 ha was sown with 'Tonic' plantain $(5 \mathrm{~kg} / \mathrm{ha})$ and a mix of annual clovers (Table 1) along with $3 \mathrm{~kg} / \mathrm{ha}$ of 'Sensation' Red clover and $2 \mathrm{~kg} / \mathrm{ha}$ of 'Nomad' white clover on 19 April 2013. The soil type was a Waipukurau sandy loam with an impervious subsoil pan resulting in the block being winter wet. Prior to sowing, agricultural lime was applied at $5 \mathrm{t} / \mathrm{ha}$ and $150 \mathrm{~kg} / \mathrm{ha}$ DAP fertiliser was applied at sowing. A 2 ha block within the paddock (TEM-C) was used to establish $15 \times 50 \mathrm{~m}$ plots of each individual annual clover along with the same rate of plantain and perennial clovers as used in the wider paddock. The area was rotationally grazed by normal farm management practices with finishing lambs (Macfarlane et al. 2015). After each paddock grazing between 29 September 2013 and 25 November 2013, a $3 \times 10 \mathrm{~m}$ area of paddock and all cultivar plots was closed off by fencing it to preclude further grazing.

At Castlepoint Station, soils were derived from mudstone with intergrades between yellow-grey and yellow-brown earths (Taihape steepland). Rainfall falls mainly over the late autumn and winter, with occasional summer rain events. Very regular and high wind run occurs during spring and early summer that constrains pasture growth (Crofoot et al. 2010). A 16.6 ha steep north facing paddock (CPS-H) with a resident pasture of crested dogstail (Cynosurus cristatus), rat's tail (Sporobolus africanus) and danthonia (Danthonia sp.) on slopes was hard grazed in the late summer autumn and on 4 April 2013 was oversown by helicopter with two annual clovers (Table 1). The area was grazed by normal farm management practices with ewes and lambs, the area being set stocked from August to early December. At 14-day intervals between 29 September 2013 and 25 November 2013, an additional $7 \times 6 \mathrm{~m}$ area of paddock was excluded from further grazing by fences. A second site (CPS-V) was established in a 10.6 ha paddock which had a similar resident pasture. The area was sprayed on 22 Nov 2012 with glyphosate (1.64 kg a.i./ha) and tribenuron-methyl (30 g ai/ha) and left as summer fallow. The area was re-sprayed in March 2013 with glyphosate $(1.325 \mathrm{~kg}$ ai/ha) and tribenuron-methyl (30 g ai/ha). Fertiliser $(250 \mathrm{~kg} / \mathrm{ha}$ Cropzeal $16 \mathrm{~N}$ ) was applied aerially on 3 April, and the following day clover seed (Table 1$)$ plus plantain $(6 \mathrm{~kg} /$ ha) was oversown by helicopter. The area was grazed by normal farm management practices with hoggets or ewes. After each grazing between 20 September 2013 and 21 December 2013, a $3 \times 10 \mathrm{~m}$ area of paddock was excluded from further grazing by fences.

At Okawa Station, a 9 ha paddock of very light soils (Poporangi sandy loam on gravels) that had previously been in permanent pasture was summer fallowed and cultivated and sown on 5 April 2003. On 15 May 2013, the area was sprayed for weeds with haloxyfop-P (130 $\mathrm{g}$ ai/ha), diflufenican (500 g ai/ha), bentazone (1.44 kg ai/ha), and chlorpyrifos (500 g ai/ha) in 125 litres water/

Table 1 Trial sites locations, long term rainfall, Olsen $\mathrm{P}$ and $\mathrm{pH}$.

\begin{tabular}{|c|c|c|c|c|c|c|}
\hline & Sites & Latitude & Longitude & $\begin{array}{c}\text { Rainfall } \\
(\mathrm{mm})\end{array}$ & $\begin{array}{l}\text { Olsen P } \\
\text { (mg/litre) }\end{array}$ & $\mathrm{pH}$ \\
\hline \multirow[t]{2}{*}{ Te Mahanga Station } & TEM-C & $39^{\circ} 46^{\prime} \mathrm{S}$ & $176^{\circ} 45^{\prime} \mathrm{E}$ & 754 & 23 & $5.1-5.5$ \\
\hline & TEM-P & $39^{\circ} 46^{\prime} S$ & $176^{\circ} 45^{\prime} \mathrm{E}$ & & & \\
\hline \multirow[t]{2}{*}{ Castlepoint Station } & CPS-V & $40^{\circ} 57^{\prime} \mathrm{S}$ & $176^{\circ} 10^{\prime} \mathrm{E}$ & 1026 & 17 & 5.7 \\
\hline & CPS-H & $40^{\circ} 55^{\prime} \mathrm{S}$ & $176^{\circ} 10^{\prime} \mathrm{E}$ & & 15 & 5.7 \\
\hline Okawa Station & OKA & $39^{\circ} 33^{\prime} \mathrm{S}$ & $176^{\circ} 41^{\prime} \mathrm{E}$ & 833 & 32 & 5.7 \\
\hline Poukawa & POU & $39^{\circ} 45^{\prime} \mathrm{S}$ & $176^{\circ} 44^{\prime} \mathrm{E}$ & 754 & 20 & 5.6 \\
\hline Inglewood & ING & $39^{\circ} 04^{\prime} \mathrm{S}$ & $174^{\circ} 13^{\prime} \mathrm{E}$ & 2349 & 10 & 5.7 \\
\hline
\end{tabular}


ha. During spring, the area was rotationally grazed with ewes and lambs. On 22 September 2013, exclusion cages $(1.5 \times 3 \mathrm{~m})$ were placed in the paddock to enable seed set.

At Poukawa (POU-T) a 12 ha paddock previously in annual ryegrass was direct drilled (Table 1) on 20 April 2013 after spraying with glyphosate $(1.64 \mathrm{~kg}$ ai $/ \mathrm{ha})$. The area was rotationally grazed with ewes and lambs. On 22 September 2013, exclusion cages $(1.5 \times 3 \mathrm{~m})$ were placed in the paddock to enable seed set.

At Poukawa (POU) and Inglewood (ING) small plots $(4 \times 4 \mathrm{~m})$ were established on 3 July 2013 by oversowing directly onto ground sprayed with glyphosate at $1.08 \mathrm{~kg}$ a.i./ha in December 2013, February and March 2014. Plots were left ungrazed to assess seed production.

All clovers were either sown as coated and inoculated seed, or seed was slurry inoculated immediately before sowing with a recommended rhizobia stain.

Approximately 6 weeks after sowing, clover establishment was measured by counting seedling numbers from 20 quadrants $\left(0.2 \mathrm{~m}^{2}\right)$. Seed heads were counted near maturity, at TEM-P, TEM-C, CPS-H and CPS-V by counting the number of flower heads in 20 sub plots $\left(0.4 \mathrm{~m}^{2}\right)$ per area at near peak flowering. Three samples of one seed head from each of 10 individual plants were collected for each cultivar from each plot Table 1). Seeds were rubbed out using soft rubber pads. Seed weight per head and 100 seed weights were determined. Three samples of 100 seeds were germinated in an incubator at $20^{\circ} \mathrm{C}$. The percentages of germinated (soft), swelled but not germinated (nonviable) and non-swelling seeds (hard) were determined after 7 days of incubation.

\section{Results and Discussion}

All clovers established at all sites except at $\mathrm{Te}$
Mahanga where arrowleaf clover failed establish after germination to because of winter wet soil conditions. At Te Mahanga, six weeks after sowing clover seedling density ranged from 273 and $411 / \mathrm{m}^{2}$ across all plots (this includes the red and white clover sown). At Castlepoint Station, total clover establishment at CPS-H averaged 138 seedling $/ \mathrm{m}^{2}$ and at CPS-V averaged 102 seedling/ $\mathrm{m}^{2}$. At Okawa, arrowleaf clover averaged 209 and Persian clover 160 seedling $/ \mathrm{m}^{2}$.

Only mature or nearly mature seed heads were counted. Because some mature seed heads might have already shed some seed, measured re-seeding is likely to have underestimated actual re-seeding. The number of mature seed heads was affected by closing date at all sites for all cultivars (Tables $2-4 ; \mathrm{P}<0.01$ ). There was no significant difference in seed weight between closing dates for any cultivars except for Persian clover where seed weight decreased with later closings $(\mathrm{P}<0.05)$. The number of seeds per head tended to be less with later closing dates for all cultivars at all sites but these differences were not significant. These effects combined to result in total seed production being significantly reduced by later closing dates for all cultivars $(\mathrm{P}<0.01)$, with the exception of gland clover which was mostly grazed to extinction prior to the first closing. Gland clover set seed only in plots that were not grazed or closed before early August. The amount of seed produced by arrowleaf, balansa and Persian clovers was considerable (ca. $200-550 \mathrm{~kg} / \mathrm{ha}$ ) if closed before late October. Balansa seed production was similar to that achieved in Australia (Craig \& Ballard 2000) and Canterbury (Monks et al. 2008). Gland clover is the earliest flowering of these four annual clovers and rotational grazing and/or set stocking were both effective in grazing plants to near extinction and they had little or no opportunity to flower. Similar poor

Table 2 Seed heads numbers and subsequent seed yield following closing at 4 dates at Sites TEM-C and TEM-P.

\begin{tabular}{|c|c|c|c|c|c|c|c|}
\hline $\begin{array}{l}\text { Site } \\
\text { Species } \\
\text { Cultivar }\end{array}$ & $\begin{array}{l}\text { TEM-C } \\
\text { Arrowleaf } \\
\text { 'Arrotas' }\end{array}$ & $\begin{array}{c}\text { TEM-C } \\
\text { Balansa } \\
\text { 'Bolta' }\end{array}$ & $\begin{array}{l}\text { TEM-C } \\
\text { Gland } \\
\text { 'Prima' }\end{array}$ & $\begin{array}{l}\text { TEM-C } \\
\text { Persian } \\
\text { 'Turbo' }\end{array}$ & $\begin{array}{c}\text { TEM-C } \\
\text { Persian } \\
\text { 'Lightning' }\end{array}$ & $\begin{array}{l}\text { TEM-P } \\
\text { Balansa } \\
\text { 'Bolta' }\end{array}$ & $\begin{array}{c}\text { TEM-P } \\
\text { Persian } \\
\text { 'Lightning' }\end{array}$ \\
\hline \multicolumn{8}{|c|}{ Seed heads $/ \mathrm{m}^{2}$} \\
\hline 29 Sep & 21 & 1070 & 0 & 1416 & 645 & 787 & 1320 \\
\hline 14 Oct & 2 & 879 & 0 & 944 & 416 & 287 & 1287 \\
\hline 28 Oct & 0 & 395 & 0 & 949 & 58 & 254 & 1091 \\
\hline 11 Nov & 0 & 170 & 0 & 602 & 25 & 170 & 462 \\
\hline \multicolumn{8}{|c|}{ Seed production (kg/ha) } \\
\hline 29 Sep & 19 & 68 & 0 & 485 & 431 & 525 & 452 \\
\hline 28 Oct & 0 & 27 & 0 & 325 & 21 & 92 & 374 \\
\hline 11 Nov & 0 & 17 & 0 & 206 & 9 & 63 & 158 \\
\hline
\end{tabular}


recovery from grazing was recorded at the Clarence MaxClover trial site (Anon 2012).

Seed yield of arrowleaf, balansa and Persian clovers was significantly depressed by a late grazing in November and December, as the terminal flowers grazed by stock were unable to be replaced. Before the end of September, plants had the ability to replace flowers that had been removed by grazing.

Closing date did not affect hardseededness in arrowleaf clover at any site, except for the very late

Table 3 Seed head numbers and subsequent seed production following closing at 5 dates at Site CPS-H.

\begin{tabular}{lrrcc}
\hline $\begin{array}{l}\text { Species } \\
\text { Cultivar }\end{array}$ & $\begin{array}{c}\text { Arrowleaf } \\
\text { 'Arotas' }\end{array}$ & $\begin{array}{c}\text { Balansa } \\
\text { 'Bolta' }\end{array}$ & $\begin{array}{c}\text { Gland } \\
\text { 'Prima' }\end{array}$ & $\begin{array}{c}\text { Persian } \\
\text { 'Enrich' }\end{array}$ \\
\hline Seed heads $/ \mathrm{m}^{2}$ & & & & \\
29 Sep $^{1}$ & 180 & 155 & 0 & 5 \\
14 Oct & 194 & 95 & 0 & 0 \\
28 Oct & 90 & 0 & 0 & 1 \\
11 Nov & 25 & 0 & 0 & 0 \\
25 Nov & 5 & 0 & 0 & 0 \\
\hline
\end{tabular}

Seed production $(\mathrm{kg} / \mathrm{ha})$

\begin{tabular}{lrrrr}
29 Sep $^{1}$ & 174 & 18 & 0 & $\mathrm{t}$ \\
14 Oct & 255 & 11 & 0 & 0 \\
28 Oct & 101 & 0 & 0 & $\mathrm{t}$ \\
11 Nov & 26 & 0 & 0 & 0 \\
25 Nov & 3 & 0 & 0 & 0 \\
\hline
\end{tabular}

${ }^{1}$ Plot accidently grazed for a short period following closing $\mathrm{t}=$ trace (less than $0.5 \mathrm{~kg} / \mathrm{ha}$ or occasional plants present)

Table 4 Seed head numbers and subsequent seed production following closing at 5 dates at Site CPS-V.

\begin{tabular}{lccc}
\hline $\begin{array}{l}\text { Species } \\
\text { Cultivar }\end{array}$ & $\begin{array}{c}\text { Arrowleaf } \\
\text { 'Arotas' }\end{array}$ & $\begin{array}{c}\text { Balansa } \\
\text { 'Bolta' }\end{array}$ & $\begin{array}{c}\text { Persian } \\
\text { 'Enrich'? }\end{array}$ \\
\hline Seed heads $/ \mathrm{m}^{2}$ & 331 & 22 & 0 \\
$20 \mathrm{Sep}$ & 306 & 8 & 0 \\
19 Oct & 156 & 0 & 0 \\
$9 \mathrm{Nov}$ & 5 & 0 & 0 \\
6 Dec & 0 & 0 & 0 \\
21 Dec & & & \\
\hline Seed production (kg/ha) & 569 & 2 & $\mathrm{t}$ \\
20 Sep & 406 & $\mathrm{t}$ & $\mathrm{t}$ \\
19 Oct & 223 & 0 & $\mathrm{t}$ \\
9 Nov & 6 & 0 & 0 \\
6 Dec & 0 & 0 & 0 \\
21 Dec & & 0 & \\
\hline
\end{tabular}

$\mathrm{t}=$ trace (less than $0.5 \mathrm{~kg} / \mathrm{ha}$ or occasional plants present)

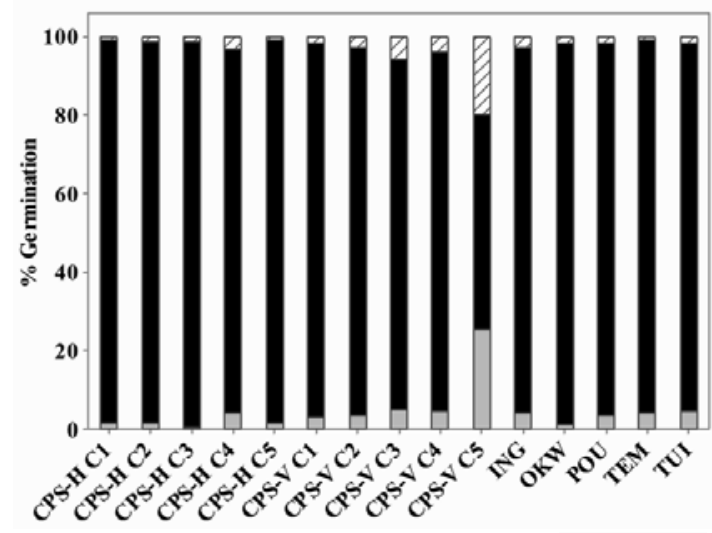

Figure 1 Arrowleaf clover - Proportions of soft, hard and non viable seed for sites (CPS-H, CPS-V for each closing dates $\mathrm{C} 1-\mathrm{C} 5)$ and for sites ING, OKW, POU TEM and TUI.

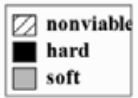

closing (Figure 1). Since the degree of hardseededness in legumes is determined by genotype, length of time taken to mature and higher temperatures (Quinlivan 1965), it is likely that the late most recent maturing seed will be less hardseeded because it has had less time to maturity time and has been exposed to lower temperatures. The high hardseedness of arrowleaf has been an issue in Australia and USA where it is not uncommon to cultivate and sow a different crop in the first year after sowing these clovers as little hard seed breaks down in the first year (Kennedy et al. 2009; Zhang et al. 2004). Poor regeneration of arrowleaf clover following successful re-seedings has been seen in the Hawke's Bay and Wairarapa (Macfarlane, unpublished data). Gland clover had very high levels of hard seed (ca. 95\%) (Figure 2), and has been described as having very hard seed under Australian conditions (Norman et al. 1998). A successful paddock scale establishment of gland clover at Castlepoint Station in 2011 resulted in a large seed set but 4 years later there has been no evidence of any re-establishment in any subsequent autumn. (A Crofoot, pers comm.).

Balansa clover produced an intermediate amount of hard seed, and earlier closing dates tended to produce more hard seed (Figure 2). At the non-summer-dry site (ING) little hard seed was produced either because climate affected hardseededness in balansa and/or physiological maturity had not been reached. Year-onyear regeneration of balansa clover from seed has been successful in Canterbury (Monks et al. 2008). Very successful regeneration of balansa clover from seed has occurred on a paddock scale in the Hawke's Bay where 2370 seedlings $/ \mathrm{m}^{2}$ were present in May 2015 producing $2880 \mathrm{~kg} / \mathrm{DM} / \mathrm{ha}$, but many other paddocks have not been successful despite large seed sets (Macfarlane unpublished results). As expected, Persian clover was 


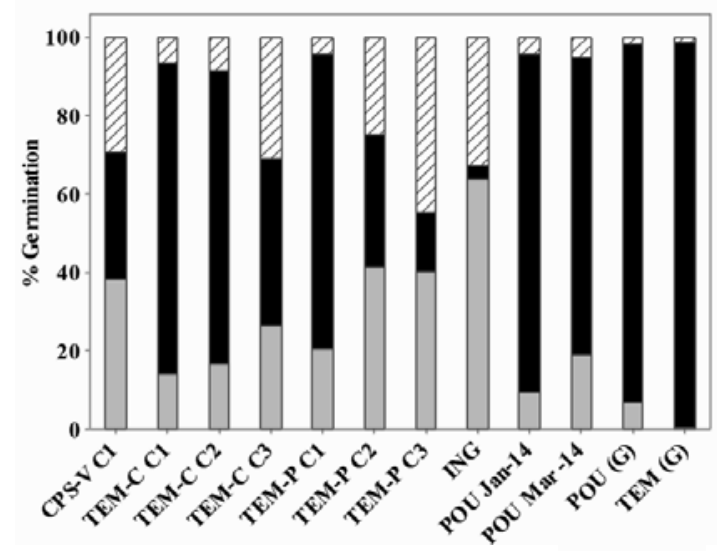

Figure 2 Balansa and gland clover Proportions of soft, hard and non viable seed for sites CPS-V closing date 1 and TEM-C and TEM-P for each closing dates C1-C3), ING, POU sampled in January 2014 and March 2014 plus gland clover $(\mathrm{G})$ sampled at sites POU and TEM.

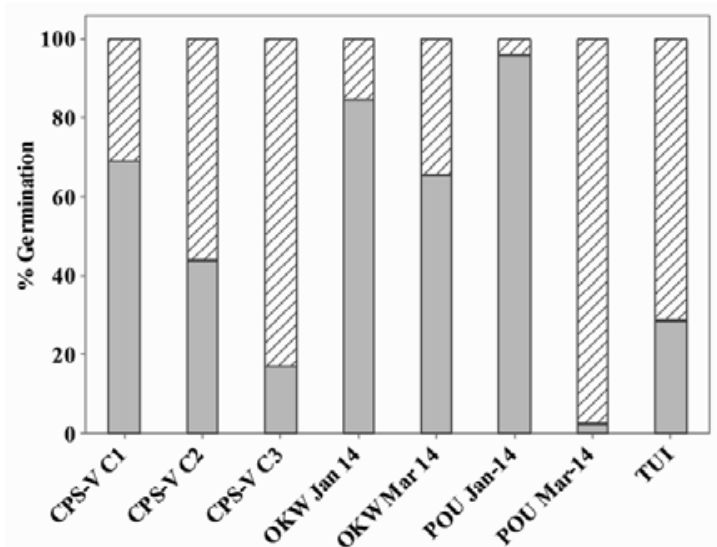

Figure 3 Persian clover - Proportions of soft, hard and non viable seed for sites (CPS-V, CPS-V for each closing dates $\mathrm{C} 1-\mathrm{C} 3$ ), OKW sampled in January 2014 and in March 2014, POU sampled in January 2014 and in March 2014 and site TUI.

very soft seeded and suffered from a high proportion of non-viable seed at harvest. Most of this was seed had imbibed water and germinated while being still being carried aerially on the plant. This correlates well with the observation that during the summer of 2013/14 that Persian clover geminated "in head" immediately after rainfall. Seed taken 2 weeks after a rain event in March 2014 contained only $2 \%$ of viable seed, $98 \%$ was non-viable (Figure 3, POU - Mar 14). This indicates that almost all seed produced was lost due to a single summer rainfall event. Seed sampled 2 months earlier contained less than $4 \%$ non-viable seed.

Experience to date with arrowleaf, balansa, gland and Persian clovers in East Coast dryland situations, has shown that while large soil seed banks have been created, in most situations, successful re-establishment within a paddock has yet to occur. However, in the South Island Balansa clover has regenerated well at some sites (R. Lucas pers. com.).

It is possible to establish these annual clovers into North Island dryland pasture situations (Macfarlane et al. 2015) however achieving a significant seed set requires stock to be removed from the paddock when it is typically needed for set stocking of ewes and lambs in the North Island. Moreover, shutting up a paddock to enable flowering and seed set of aerially seeding annual clovers will result in large amounts (ca. 4000$6000 \mathrm{~kg} \mathrm{DM} / \mathrm{ha}$ ) of unpalatable dry matter (Macfarlane unpublished results), which will require intensive efforts to control and manage. Once a seed reserve is established, bare ground and control of existing vegetation in each autumn will be essential to reduce competition to enable the clover seedlings to develop.

\section{Summary}

- Until management systems are developed that enable production of soil seed reserves and the creation of an environment suitable for successful annual re-establishment, arrowleaf, balansa and Persian clovers should only be used by annual sowings for late winter-early summer for forage production.

- Gland clover is unsuitable for North Island $>800 \mathrm{~mm}$ rainfall dryland pasture zones because it flowers too early to be able to exploit the longer growing season, and it is extremely hardseeded.

- Most Persian clover cultivars sold in New Zealand are of the sub-species 'majus', all producing little or no hard seed. Because of the risk of early germination, cultivars of ssp. 'majus' can only be recommended for sowings as a one-off annual (i.e. there is no expectation for it to reseed). In this situation they can perform very well. Tolerance of wet soils and high spring growth rates (ca. 85-95 kg $\mathrm{DM} / \mathrm{ha} /$ day, (Muir, unpublished data) can provide excellent lamb finishing feed (Muir, unpublished data) and significant amounts of $\mathrm{N}$ for subsequent crops. Persian clover can be used successfully to complement arrowleaf clover in paddocks with variable drainage.

- The later maturing and flowering arrowleaf clover cultivar 'Arrotas' has very high levels of hardseededness and will not regenerate seedlings in its first autumn. It is therefore difficult to manage in permanent pastures. When sown as an annual crop very high growth rates in late spring $(85-110 \mathrm{~kg} \mathrm{DM} /$ 
da/day, unpublished results) supplying excellent feed for weaned lambs.

- Balansa clover - 'Bolta' balansa clover appears to have most potential for use in dryland pastoral systems. It produces a balance of hard and soft seed and is tolerant of wet soil conditions. It has high DM production potential in the first half of spring. It can be grazed at least a month before lucerne is ready for its first grazing (Lucas, pers com). Once a large seed crop has been produced in its first spring, hard grazing through late summer has resulted in sufficient seedlings establishing in autumn. The first year seed set should carry over for at least three 3 years.

\section{ACKNOWLEDGEMENTS}

The authors gratefully acknowledge the assistance of Tom Lowry of Okawa Station, Guy Hamilton and Cameron Lane of Brownrigg Agriculture and Tom Bush of Castlepoint Station. Kay Ward and Alex Cadet for detailed seed work and Peter Swinburn and members of the Beef + Lamb Farmer Council for their over-sight and direction of the project. This work was funded by MPI's Sustainable Farming Fund (Grant 11/104), Beef + Lamb NZ and the Hawkes Bay Regional Council.

\section{REFERENCES}

Anon 2003. Persian clover Agfact P2.5.26 NSW Department of Primary Industries.

Anon 2012. Annual clover performance on medium rainfall hill country. FITT Report 11FT12. http://www.beeflambnz.com/Documents/Farm/ Annual\%20clover\%20performance $\% 20$ on $\% 20$ medium\%20rainfall\%20hill\%20country.pdf

Craig, A.D. 1998. Register of Australian herbage plant cultivars. B. Legumes. 1. Clover. Trifolium michelianum Savi (balansa clover). cv. Bolta. Australian Journal of Experimental Agriculture 38: 531-532.

Craig, A.D.; Ballard, R. A. 2000. Balansa clover (Trifolium michelianum) - a forage legume for temperate pastures Cahiers Options Méditerranéenes 45: 177-180.

Crofoot, A.N.; Crofoot, E.W.; Hoogendoorn, C.J.; Litherland, A.J; Garland, C.B. 2010. N-leaching in hill country; farmer led research. Proceedings of the New Zealand Grassland Association. 72: 55-60

Dear, B.S.; Sandral, G. .; Wilson, B C D.; Rodham, C.A.; and McCaskie, P. 2002. Productivity and persistence of Trifolium hirtum, T. michelianum, T. glanduliferumand, Ornithopus sativus sown as monocultures or in mixtures with T. subterraneum in the south-eastern Australian wheat belt. Australian Journal of Experimental Agriculture 42: 549-556.
Evans, P. M. 2006. Agriculture Notes, Arrowleaf clover. AG0576 ISSN 1329-8062. Department of Primary Industries, Victoria, Australia.

Evans, P.M.; Mills, A. 2008. Arrowleaf clover: potential for dryland farming systems in New Zealand. Proceedings of the New Zealand Grassland Association 70: 239-243

Evans, P. M.; Snowball, R. 1993. Balansa and Persian clover lines outproduce registered cultivars, and subterranean clover and medics, in a $400 \mathrm{~mm}$ annual rainfall zone in Western Australia. pp. 5356 In: Proceedings of 7th Australian Agronomy Conference. Eds. McDonald, G.K.; Bellotti, W.D. The University of Adelaide, 19-24 September 1993.

Evans, P.M.; Zhang, X; Riffkin, P.A. 2003. Annual pasture legumes for farming systems in cool temperate areas with summer soil moisture deficits. Legumes for Dryland Pastures. Grassland Research and Practice Series 11: 149-154.

Hackney, B.; Dear, B.; Sandral, G. 2007. Gland clover. Primefact 634. Department of Primary Industries. New South Wales

Hyslop, M.G.; Slay, M.W.A.; Moffat, C.A. 2003. Dry matter accumulation and sheep grazing preference of six winter active annual legumes. Legumes for dryland. Grassland Research and Practice Series 11: 117-122.

Kennedy, A.J.; Thompson, A.N.; Drum, J.A.; McCaskill, M.R. 2009. Arrotas Arrowleaf Clover Establishment and management guide for livestock production systems. Department of Environment and Primary Industries, Melbourne, Victoria.

Macfarlane, M.J.; Muir, P.D.; Crofoot, E.W. 2015. The role of plantain (Plantago lanceolata) on East Coast dryland: results from three farm case studies. Proceedings of the New Zealand Grassland Association 77: 103-108.

Monks, D.P.; Moot, D.J.; Smith, M.C.; Lucas, R.J., 2008. Grazing management for regeneration of balansa clover in a cocksfoot pasture. Proceedings of the New Zealand Grassland Association 70: 233-238

Norman, H.C.; Cocks, P.S.; Smith, F.P.; Nutt, B.J. 1998. Reproductive strategies in Mediterranean annual clovers: germination and hardseededness. Australian Journal of Agricultural Research 49: 973-982.

Nutt, B. J.; and Loi, A. 2002. Prima gland clover. Farmnote no. 4/2002. Department of Agriculture Western Australia, Perth, Australia.

Quinlivan, B. J. 1965. The influence of the growing season and the following dry season on the hardseededness of subterranean clover in different environments. Australian Journal of Agricultural Research 16: 277-291. 
Sheath, G.W.; Macfarlane, M.J.; Bonish, P.M. 1984. Evaluation of arrowleaf clover (Trifolium vesiculosum) in North Island hill country: nodulation and reseeding. New Zealand Journal of Experimental Agriculture 12: 209-217

Williams, W.M.; Caradus, J.R.; Charlton, J.F.L. 1980. Plant introduction trials: Comparative performance of annual legume species at three sites in the southern North Island. New Zealand Journal of Experimental Agriculture 8: 185-190.

Zhang, X.; Evans, P.M. 2004. Grain yield production in relation to plant growth of wheat and canola following clover pastures in southwest Victoria. Australian Journal of Experimental Agriculture 44: 1003-1012. 
